\title{
GOD AND THE SUFFERING OF HIS PEOPLE
}

\author{
J. E. T. Kuwornu-Adjaottor \\ Department of Religious Studies, Faculty of Social Sciences, KNUST, Kumasi \\ E-mail: jettete@yahoo.com, jkadjaottor@gmail.com
}

\begin{abstract}
The problem of suffering is a multifaceted one. It has moral, physical, philosophical, psychological and theological dimensions. Suffering is said to be a moral problem because some belief that it occurs as a result of sin against God and the spirits. Physically, we experience unpleasant things as human beings, thus we suffer. Philosophically the problem of suffering gives a rational explanation to the existence of God and suffering in the world. Psychologically it deals with how to comfort those who suffer hurt which might make them to develop a dislike for God. Theologically it has to do with the question believers in God ask when they go through suffering. In this paper the author posits, from a theological perspective that, God does not take delight in the sufferings of his people; he wrestles with the shortcomings/sufferings of his people, an activity of him we cannot fully understand. God teaches us valuable lessons through suffering. We may experience suffering to: make us humble, grow stronger, and equip us to comfort others in their suffering. God always knows what is best and he never makes a mistake. Thus when believers suffer, they must stand firm and depend on God.
\end{abstract}

Keywords: Suffering, theodicy, God, evil

\section{INTRODUCTION}

Human suffering falls under the broad phenomenon of evil. There are two types of evil moral evil and physical evil, which some people refer to as natural evil. Moral evil is internal to the agent. Physical evil is external to the agent. Moral evil is simply sin - offence against God. Physical evil consists of all the unpleasant things that happen to us as human beings. According to some people, physical suffering is often, not always, the result of moral evil. In other words, God or the spirits punish human beings with all kinds of calamities, diseases, epidemics, earthquakes; you name it, when we offend them. Physical evils show themselves in sufferings of various types.

From the explanations above, it is clear that the term 'suffering' is closely allied to the concepts of evil and pain. Human suffering abounds all over the world. It is part of the problem of evil. Epicurus is supposed to have given the problem 


\section{Kuwornu-Adjaottor}

of evil the classic formulation as follows: Either God would remove evil out of this world, and cannot; or He can, and will not; or He has not the power nor will; or $\mathrm{He}$ has both the power and the will. If $\mathrm{He}$ has the will, and not the power, this shows weakness, which is contrary to the nature of God. If He has the power, and not the will, this is malignity, and is no less contrary to His nature. If He is neither able nor willing, He is both impotent and malignant, and consequently cannot be God. If He is both willing and able (which alone is consonant to the nature of God), then whence comes evil, or why does He not prevent it? (Hunnex, 1986:35).

The problem of evil has perplexed many generations of philosophers. But what is more difficult to explain is the suffering brought to humanity by natural causes in the world - disasters such as floods, earthquakes or tornadoes; different sorts of diseases such as smallpox, polio, congenital disabilities such muscular dystrophy, cerebral palsy or encephalitis cancer or leukemia; accidents and injuries such as being burned, crushed or drowned.

The problem of evil and suffering has been considered philosophically by many since the seventeenth century. Two Protestant thinkers who championed this cause were Godttfried von Leibniz (1646-1716) and Friedrich Schleiermacher (1768-1834). Leibniz, the first to coin the term 'theodicy' declared that God, who created the world and ordained human freedom, could still bring good out of the resulting evil. Schleiermacher argued that sin and suffering, even though are result of humanity's conscious activities, God is ultimately responsible (Hurding 1995:825). Scholars who have continued the enquiry into the problem of evil and suffering include, John Hick and Alvin Plantinga. Hick, whose 'soul-making' approach looks to Irenaeus of Lyons, sees the eventual resolution of evil and adversity in the perfectibility of human nature in the 'likeness' of God
(Hick, 1977). Plantinga, whose 'free-will defence' is influenced by Augustine of Hippo, postulates that an omnipotent and wholly good God, in creating human choice, inevitably permits evil and suffering (Plantinga, 1974).

The First and Second World Wars in particular have heightened theological reflection on the cross in the face of unwarranted human suffering. Thinkers who championed discussions on the issue include Peter Taylor Forsyth, who in seeking to justify God in the context of the First World War, rejected the remoteness of traditional philosophy and offered a Christocentric approach in which 'the only theodicy is that which redeems' (Forsyth, 1916). Dorothee Soelle criticises passivity in relation to suffering as 'Christian masochism' and urges a social response to sufferers which expresses solidarity with the suffering of Christ (Soelle, 1975). Jürgen Moltmann positioned his theodicy in a theology of the cross, the identification of the Trinitarian God with suffering of humanity and the eschatological hope of triumph over evil (Moltmann, 1974). Kenneth Surin, in the light of the horror of Auschwitz, declares a 'rapture' of language and the need for unbelief, as well as belief, in relation to God's apparent inaction; and adds that, the only legitimate response to such unspeakable suffering, is that of 'penance and conversion'(Surin, 1986).

Other solutions to the problem of evil/suffering have been attempted. One of such is Finitism. One of its proponents, Brightman, says finitism teaches that God is a personal consciousness of eternal duration, an eternally active will, who works with the 'Given.' The 'Given' in this context means the eternal, uncreated laws of reason. This includes the uncreated processes of nonrational consciousness which exhibit all the ultimate qualities of sense objects, disorderly impulses and desires; all of which manifest in pain and suffering (Brightman, 1940).

Finitism, which rejects the Omnipotence of God, raises a question mark on the goodness of God. It has made evil and suffering part of 
God's nature. Hick (1977:39) poses the question on Brightman's position when he asks: "If the 'Given' with which God struggles and which is the source of the surd evil is a part of God's own nature, how can he be referred to as good?" I object to finitism because if God is not omnipotent, then it means that he has failed in his plans. But the fact that there is evil and suffering in the world does not mean God has failed in his plans. To borrow David Paulsen's terminology of the "redemptive sovereignty of God", (Paulsen, 1999), I opine that "God is redemptively sovereign", meaning he is sufficiently powerful that he can ensure our redemptive salvation. God has created human beings to help get rid of evil in the world, but evil and suffering exist because human beings are doing very little to eradicate them.

Theistic determinism is another proposal for a solution to the problem of evil/suffering in the world. One of the champions of this position is Gordon H. Clark, who posits that an act is caused by God. God is the only cause. Thus, totally free human choice is eliminated (Clark, 1961). Clark describes God as causing all things, including human acts. He argues that the human will is not free in describing the relationship of God to certain evil actions of human beings, and rejects the concept of the permissive will of God. Clark's argument raises the question of whether God is the cause of evil and suffering. Clark, in response to his proposition of theistic determinism redefines the goodness of God by saying that, "whatever God does is just and right simply because he does it. There is no law superior to God which forbids him to decree sinful acts. Sin is transgression of, or want of conformity to the law of God. But he is ex-lex, that is, above the law. He is by definition the standard of right" (Clark, 1961:239-240). I object to Clark's opinion in the sense that laws are made for humans to obey and since God is not human he has no law to obey. He is free to do anything though. But because by nature God is good, we cannot attribute evil in the world to him.
A third proposed solution to the problem of evil rejects the reality of evil and consequently suffering. This position renders unnecessary, any account of how evil/suffering can coexist with an omnipotent and good God. A proponent Benedict Spinoza, for example maintains that there is just one substance and all distinguishable things are modes or attributes of that substance. Everything is deterministically caused; God brings everything into being in the highest perfection (Spinoza, 2001). This theory that denies evil and suffering does not make sense because human suffering is real. The natural disasters, different sorts of diseases, congenital disabilities, accidents and injuries, all point to the reality of suffering in the world.

I admit that a good and loving God's coexistence with evil in the world is not an easy thing to explain. However, since I am not writing this article to debunk the stand of nonbelievers who denigrate the idea of a Creator God; but to console readers who might have problems with suffering, and also to strengthen the faith of those who may have believed in God but are being threatened with temptation to fall into fatalism, my position is that God teaches us valuable lessons through suffering. We may experience suffering to make us humble, grow stronger, and equip us to comfort others in their suffering. These reasons may not be convincing enough, but one consolation we can give ourselves in times of suffering is that God always knows what is best, and he never makes a mistake.

\section{SUFFERING IS BOTH AN INTELLEC-} TUAL AND AN EMOTIONAL PROBLEM

The problem of suffering which is also the problem of evil is both intellectual and emotional (Moreland \& Craig, 2003). The intellectual problem of suffering is about how to give a rational explanation to the existence of God and suffering in the world. When people suffer, their minds grapple with the question "why me?" The human being wants to know whether there is a reason behind his suffering. The question of "why me?" in times of suffering stems 


\section{Kuwornu-Adjaottor}

from the theological answers to the question, "What is God really like? (see Erickson, 2001:289-370). Christian theologians have answered this question by saying "God is allPowerful; God is good'. Thus the problem of suffering has a theological dimension. Christians believe in a God who is totally, thoroughly good, with no badness in him whatsoever. It follows that a person who has a problem will ask, "why has God allowed it?" (Pawson, 2007). If God is all-powerful and all-loving, then why should his creation suffer? In other words, where is God when people suffer? How does he wrestle with our suffering?

For many people, the problem of suffering is not really an intellectual problem; it is an emotional problem. The emotional problem of suffering concerns how to comfort those who are suffering and how to dissolve the emotional dislike of a God who would permit such sufferings. Emotionally, people suffer hurt inside, and are perhaps bitter against a God who would permit them or others to suffer so. They ask, "Why me?", "Why did God allow this to happen to me?" Many "whys" are poetic questions, symbolic ways to express the depths of one's misery. Christian theology has resources to deal with the problem of suffering. It teaches that God is not a distant Creator or impersonal ground of being, but a loving Father who shares our sufferings and hurts with us. Plantinga writes:

As the Christian sees things, God does not stand idly by, coolly observing the suffering of his creatures. He enters into and shares our suffering. He endured the anguish of seeing his son, the second person of the Trinity, consigned to the bitterly cruel and shameful death on the cross. Some theologians claim that God cannot suffer. I believe they are wrong. God's capacity for suffering, I believe is propositional to his greatness; it exceeds our capacity for in the same measure as his capacity for knowledge exceeds ours. Christ was prepared to endure the agonies of hell itself; and God, the Lord of universe, was prepared to endure the suffering consequent upon his son's humiliation and death. He was prepared to accept this suffering in order to overcome sin, and death, and the evils that affect our world, and to confer on us a life more glorious than we can imagine. So we do not know why God permits evil; we do know, however, that he was prepared to suffer on our behalf, to accept suffering of which we can form no conception (Plantinga, 1974:36).

God wrestles with our sufferings; he cares when we suffer. God's wrestling with our suffering is imbedded in the suffering Christ endured which is beyond all understanding. He bore the punishment of the sins of the whole world. None of us can comprehend that suffering. Though he was innocent, he voluntarily underwent incomprehensible suffering for us. He did that because he loves us so much. Thus, the most important thing to do when somebody is undergoing suffering is for one to be there as a loving friend and sympathetic listener.

\section{RECENT CONTRIBUTIONS TO THE IN- TELLECTUAL PROBLEM OF SUFFER- ING}

The question of suffering remains high on the agenda of modern theology. This has been given a new sense of urgency and importance through the impact of the horrors of World War II, and the continued struggle of oppressed people against those who oppress them. McGrath has noted a number of approaches each of which can be set against a different backdrop.

First, Liberation theology develops a distinctive approach to suffering, based on its emphasis upon the poor and the oppressed. The suffering of the poor is not viewed as passive acquiescence in suffering; rather, it is seen as participation in the struggle of God against suffering in the world - a struggle which involves direct confrontation with suffering itself. This idea in various forms can be discerned in the writings of Latin American liberation theologians. However, it is generally thought to find its most 
powerful expression in the writings of Black theology, especially those of James Cone. The sequence of the cross and resurrection is interpreted in terms of a present struggle against evil, conducted in the knowledge of God's final victory over all suffering and that which causes it. Similar things can be noted in the writings of Martin Luther King, especially his "Death of Evil upon the Seashore".

Second, Process theology locates the origin of suffering and evil within the world in a radical limitation upon the power of God. God has set aside the ability to coerce, retaining only the ability to persuade. Persuasion is seen as a means of exercising power in such a manner that the rights and freedoms of others are respected. God is obliged to persuade every aspect of the process to act in the best possible manner. There is however no guarantee that God's benevolent persuasion will lead to a favourable outcome. The process is under no obligation to obey God. God intends good for the creation, and acts in its best interests. However, the option of coercing everything to do the divine will cannot be exercised. As a result, God is unable to prevent certain things happening. Wars, famine and holocausts are not things which God desires; they are, however, not things which God can prevent, on account of the radical limitations placed upon the divine power. God is thus not responsible for evil; nor can it be said, in any way, that God desires or tacitly accepts its existence. The metaphysical limits placed upon God are such as to prevent any interference in the natural order of things.

Third, another strand in recent times on suffering has drawn upon Old Testament themes. Jewish writers such as Elie Wiesel, retaining at least the vestiges of a belief in the fundamental goodness of God, point to the numerous passages in the Old Testament which protest against the presence of evil and suffering in the world. This approach has been picked up by Christian writers, including John Roth, who has named the approach "protest theodicy." The protest in question is seen as part of the faithful and trusting response of a faithful people to their God, in the face of uncertainties and anxieties concerning God's presence and purposes in the world (McGrath, 2001:295-296).

Contemporary theological discussions on suffering are that: God is perhaps limited in his dealing with evil in the world, because he is confronted with the issue of respecting the rights and freedom of people. Suffering of humankind is a participation in the struggle God goes through as he confronts evil in the world. Evil, which manifest in the suffering of people, must be protested by the people of faith, on the basis of God's goodness.

Ehrman (2008) also wrestles with the problem of suffering, and after meditating on how the Bible explains human suffering, finds the explanations unconvincing, and so gave up on being a Christian. He uses a theological approach to arrive at his answer to the problem. He asks, if God is all powerful and all-loving, how can suffering exist? Through close readings of sections of the Old and New Testaments, he discovers that the Bible offers numerous answers that are often contradictory. The prophets think that God sends pain and suffering as a punishment for sin, and also that human beings who oppress others create such misery. The writers who tell the Jesus story and the Joseph story think God works through suffering to achieve redemptive purposes. The writer of the book of Job views pain as God's test; and the writers of Job and Ecclesiastes conclude that we simply cannot know why we suffer. Although his readings of the biblical texts are instructive, he fails to convince readers that these are indeed God's problems, and thus, refuses to accept the standard theological answers.

HOW TO DEAL WITH THE EMOTIONAL PROBLEM OF SUFFERING

There are three ways to deal with the emotional problem of suffering.

Understand that God does not enjoy our Pain and Suffering 


\section{Kuwornu-Adjaottor}

When we go through pain and suffering, it is important to understand that God is not happy. He did not initially create pain, grief, and suffering as part of his plan for mankind in the original perfect state of humankind. Everything he created was very good (Genesis 1:31). There was no disease, drought, wars and catastrophes, death, and $\sin$ in the life of the first people God created. There was invasion of the earth by Satan after the rebellion of Lucifer in heaven (Isaiah 14:12-14; Ezekiel 28:12-15)). Then Satan planned to destroy the relationship between God and humankind by craftily devising temptation for the first people God made in order to make them sin against God and incur his displeasure. Adam and Eve yielded to the deceit of the devil in the Garden of Eden and brought a sin barrier between God and themselves, and thereby marred the original sweet, holy fellowship they had with their Maker (Genesis 3:8-9).

The ultimate consequences were the separation from God's presence (but not from his love), punishment, and curse from God. These consequences invited all the trials, temptations, diseases, oppression, accidents, disasters, wars, calamities, suffering, pain, evil, and all the varieties of problems that have continually plagued and devastated humanity (Genesis 3:124). Thus it is not God who makes us suffer. He does not intentionally and willingly bring suffering as part of his affliction on men (Lamentations 3:33). Rather, he allows suffering, pain, trouble, disaster, calamity, and grief to come into our lives for his divine purpose, most of which our minds are too finite to comprehend and explain (Job 1 and 2).

Some sufferings that come our ways are not as a result of our doings

There are some sufferings that people go through which are not as a result of their faults. They suffer from a coincidence. Such sufferings are those from natural causes or disasters earthquakes, tornadoes, storms, floods, drought, crop failures, landslides, animal attacks, fires, tree falls, and outbreak of infectious diseases.
People may experience suffering also as a result of people's actions (mistakes or ignorance). An example is found in the story of Joseph. Scripture clearly says that Joseph's brothers were wrongly jealous of him (Genesis 37:11), hated him (Genesis 37:4,5,8), wanted to kill him (Genesis 37:20), and did wrong when they cast him into a pit (Genesis 37:24) and then sold him into slavery in Egypt (Genesis 37:28).

\section{God allows trials and sufferings in our lives for a purpose}

Sometimes God allows us to go through suffering for a season in order that he might teach us some important lessons, so that we can become humbled, strengthened in our faith, and toughened in our character (Psalm 23:4). God permits suffering to come on his people so that he can get their attention (Psalm 103:4; 119:67, 92; Exodus 15:26). When we suffer, God might be preparing us for greater blessings ahead (John 15:1-5; Romans 8:18; 2Corinthians 4: 17, $18)$.

\section{CONCLUSION}

The problem of suffering is categorised under the broad phenomenon of evil which is both moral and physical. Moral evil is sin against God whilst physical evil consists of the unpleasant experiences we go through as human beings. Suffering also has philosophical, psychological and theological dimensions. The philosophical aspect is intellectual and it confronts one with the question, "why me?", when one suffers. The psychological dimension is emotional; it finds ways of comforting those who are suffering. Theologically, it provides answers to the question, "Where is God when believers in God suffer?" The truth is that God wrestles with the shortcomings of his people, an activity of him we cannot fully understand. He responds when we are suffering (McDonald, 1986). God teaches us valuable lessons through suffering. We may experience suffering to make us humble, grow stronger, and equip us to comfort others in their suffering. God always knows what is best, and he 
never makes a mistake. Thus, he wants believers to stand when life throws them off balance (Littleton, 1986). This is because they shall overcome their trials and suffering (Kisseadoo, 2006), when they face the fight and depend on God through the storm (Kisseadoo, 2011).

\section{REFERENCES}

Brightman, E. S. (1940). A Philosophy of Religion. New York: Prentice-Hall Inc.

Clark, G. H. (1961). Religion, Reason, and Revelation. Philadelphia: Presbyterian and Reformed.

Erhrman, B. D. (2008). God's Problem: How the Bible fails to answer our most important question - Why we suffer. New York: Harper Collins.

Erickson, M. J. (2001). Christian Theology, $2^{\text {nd }}$ ed., Grand Rapids, Michigan: Baker Books.

Forsyth, P. T. (1916). The Christian ethic of war. California: University of California Libraries.

Hick, J. (1977). Evil and the God of love. London and New York: Harper \& Row.

Hureding, R. (1995). Suffering. In: Atkinson, D. et al, eds. New Dictionary of Christian Ethics and Pastoral Theology. Leicester: InterVasity Press.

Hunnex, M. D. (1986). Chronological and Thematic Charts of Philosophies and Philosophers. Grand Rapids, Michigan: Zondervan.

Kisseadoo, S. V. A. (2006). Overcoming trials and suffering. Accra: Asempa Press/Christian Council of Ghana.

Kisseadoo, S. V. A. (2011). Facing and fight ing through the storm. Accra: Wrenco Ltd.

Littleton, M. R. (1986). A Place to stand when life throws you off balance. Port- Oregon: Multnomah Press.

McDonald, H. D. (1986). The God who responds. Minneapolis, Minnesota: Bethany House Publishers.

McGrath, A. E. (2001). Christian Theology: An Introduction, $3^{\text {rd }}$ ed., Oxford: Blackwell Publishers Inc.

Moltmann, J. (1974). The Crucified God. London: SCM Press/ Minneapolis: Fortress Press.

Moreland, J. P. and Craig, W. L. (2003). Philosophical Foundation for a Christian Worldview. Downers Grove, Illinois: InterVarsity Press.

Paulsen, D. (1999). 'The God of Abraham, Isaac, and (William) James'. Journal of Speculative Philosophy 13, 2 : 114-146.

Pawson, D. (2007). Why does God allow natural disasters? Bradford: Tera Nova Publications.

Plantinga, A. C. (1974). God, freedom, and evil. Grand Rapids, Michigan: Eerdmans.

Soelle, D. (1975). Suffering. London and Philadelphia: Fortress Press.

Spinoza, B. (2001). Ethics. New York: Wordworth Publishers

Surin, K. (1986). The Theology and problem of evil. Oxford and New York: Blackwell. www.dialoguejournal, accessed 14/3/13 